\title{
Guanosine Nucleotides Regulate B2 Kinin Receptor Affinity of Agonists But Not of Antagonists: Discussion of a Model Proposing Receptor Precoupling to G Protein
}

\author{
Alexander Faussner*,a and Adelbert A. Roscher \\ Dr. von Haunersches Kinderspital der \\ Universität München, Abteilung für Klinische Biochemie, \\ Lindwurmstr. 4, D-80337 München, Germany \\ *Corresponding author
}

The effect of nucleotides on binding of the B2 kinin (BK) receptor agonist $\left.{ }^{3} \mathrm{H}\right] \mathrm{BK}$ and the antagonist $\left[{ }^{3} \mathrm{H}\right] \mathrm{NPC} 17731$ to particulate fractions of human foreskin fibroblasts was studied. At $0^{\circ} \mathrm{C}$, particulate fractions exhibited a single class of binding sites with a $K_{d}$ of $2.3 \mathrm{~nm}$ for $\left[{ }^{3} \mathrm{H}\right] \mathrm{BK}$ and a $K_{d}$ of $3.8 \mathrm{~nm}$ for the antagonist $\left[^{3} \mathrm{H}\right] \mathrm{NPC} 17731$. Incubation with radioligands at $37^{\circ} \mathrm{C}$ for 5 min gave a reduction of agonist, as well as antagonist, binding that was between $0-40 \%$ depending on the preparation, even in the absence of guanosine nucleotides. As shown by Scatchard analysis, this reduction in specific binding was due to a shift in the affinity of at least a fraction of the receptors. The presence at $37^{\circ} \mathrm{C}$ of the guanine nucleotides GTP, GDP and their poorly hydrolyzable analogs left $\left[{ }^{3} \mathrm{H}\right]-$ NPC 17731 binding unaffected, but reduced the receptor affinity for $\left[{ }^{3} \mathrm{H}\right] \mathrm{BK}$ to a $\mathrm{K}_{\mathrm{d}}$ of about $15 \mathrm{nM}$. The maximal number of receptors, however, was unchanged. This affinity change was strongly dependent on the presence of bivalent cations, in particular $\mathrm{Mg}^{2+}$. It was reversed by incubation at $0^{\circ} \mathrm{C}$. The rank order of the guanosine nucleotides for $\left[{ }^{3} \mathrm{H}\right] \mathrm{BK}$ binding reduction was GTP $[\gamma \mathrm{S}]=\mathbf{G p p}[\mathbf{N H}] p>\mathbf{G T P}=\mathrm{GDP}>\mathrm{GDP}[\beta S]$. GMP, ATP, ADP and AMP showed no influence on agonist binding. A model for the interaction of the $B 2$ kinin receptor with $\mathbf{G}$ proteins is discussed.

Key words: Bradykinin / $\mathrm{G}$ protein coupling.

\section{Introduction}

The nonapeptide bradykinin (BK) is released from high molecular weight precursors, the kininogens, via the action of proteolytic enzymes known as kallikreins. Generation of BK and or lysyl-BK (kallidin) frequently occurs in response to tissue injury or inflammation, where these

\footnotetext{
a Present address: Abteilung für Klinische Chemie und Klinische Biochemie, Universität München, Nussbaumstr. 20 , D-80336 München, Germany
}

peptides can exert a variety of biological effects, including vasodilatation, increased vascular permeability, stimulation of pain and hyperalgesia, and enhanced cell proliferation (Proud and Kaplan, 1988; Bhoola et al., 1992). According to pharmacological criteria, these effects are mediated by at least two different receptors, B 1 and B2 receptors (Regoli and Barabe, 1988; Farmer and Burch, 1992). Radioligand binding studies proved the existence of $B 2$ receptors in a variety of tissues and cell lines (Bathon and Proud, 1991). Recently the rat, mouse and human $B 2$ kinin receptors, as well as the human B1 kinin receptor, have been cloned (McEachern et al., 1991; Hess et al., 1992; Menke et al., 1994; Webb et al., 1994) and, based on sequence homology, were grouped into the superfamily of the $G$ protein-coupled receptors (GPCRs). These findings were in agreement with previous reports, that $\mathrm{BK}$, via the $\mathrm{B} 2$ receptor, is capable of activating phospholipase $A$ and/or $C$ and of inhibiting adenylate cyclase via signal transduction pathways that utilize guanosine nucleotide regulatory proteins (Liebmann and Reissmann, 1990; Gutowski et al., 1991; Liebmann et al., 1991; McEachern etal., 1991; Tippmer et al., 1994). However, both the subtype of the $G$ protein(s) involved, as well as the effect of guanine nucleotides on $\left[{ }^{3} \mathrm{H}\right] \mathrm{BK}$ binding sites, are not completely understood. It has been reported that in human fibroblasts (Etscheid and Villereal, 1989) and in bovine aortic endothelial cells (Keravis et al., 1991) addition of guanosine nucleotides may induce a reduction of B2 kinin receptor number. In other studies, a change in affinity of $B 2$ kinin receptors (Burch and Axelrod, 1987; Leeb-Lundberg and Mathis, 1990; Liao and Homcy, 1993) or changes in both affinity and receptor number (M athis and Leeb-Lundberg, 1991) were reported. By contrast, guanosine nucleotides were reported to inhibit $\left[{ }^{3} \mathrm{H}\right] \mathrm{BK}$ binding to the human $\mathrm{B} 2$ kinin receptor expressed in COS-7 cells (Hess etal., 1992), while no effect of these nucleotides was observed on BK binding to receptors in guinea pig lung (Trifilieff et al., 1994).

Cultured human foreskin fibroblasts express high numbers of B2 kinin receptor, which, when occupied by agonist, are subject to strict regulatory control via internalization and down-regulation (Roscher et al., 1984). Although $\mathrm{G}$ proteins appear to couple these receptors to the synthesis of eicosanoids, thereby accumulating CAMP and the release of inositol phosphates (Roscher et al., 1983; Burch and Axelrod, 1987; Dengler et al., 1990), little is known regarding the exact mechanism of the interaction between the $B 2$ kinin receptor and these $G$ proteins. In this study, we compared the effect of guanine nucleotides on B2 kinin receptor agonist and antagonistbind ing to partic- 
ulate fractions of human foreskin fibroblasts at $0^{\circ} \mathrm{C}$ and at $37^{\circ} \mathrm{C}$.

We were able to demonstrate that at $37^{\circ} \mathrm{C}$ the guanosine nucleotides GTP and GDP, and their hydrolysis-resistant analogs, induce a reduction in affinity without a concomitant loss of receptor number in the presence of agonist, but not antagonist. This affinity reduction was reversible by incubation on ice, indicating that at $0^{\circ} \mathrm{C}$ the $\mathrm{B} 2$ kinin receptor is always in a high-affinity state and therefore presumably coupled to $\mathrm{a} G$ protein.

\section{Results}

\section{$\left[{ }^{3} \mathrm{H}\right] \mathrm{BK}$ Binding to Particulate Fractions of Human Foreskin Fibroblasts at $37^{\circ} \mathrm{C}$ in the Absence and Presence of Gpp[NH]p}

P reliminary experiments with particulate fractions showed that binding of $\left[{ }^{3} \mathrm{H}\right] \mathrm{BK}$, even in the absence of exogenous guanosine nucleotides, rapidly decreased in some preparations with time at $37^{\circ} \mathrm{C}$, but was stable in all preparations at $0{ }^{\circ} \mathrm{C}$ for at least three hours. Therefore, for experimental convenience, all incubations were prepared on ice and kept on ice for up to two hours until being used for studies at $37^{\circ} \mathrm{C} .\left[^{3} \mathrm{H}\right] \mathrm{BK}$ binding activity measured after a $90 \mathrm{~min}$ incubation on ice was referred to as the maximum binding capacity of the preparation used.

In Figure 1 the time course of specific $\left[{ }^{3} \mathrm{H}\right] \mathrm{BK}$ binding at $37^{\circ} \mathrm{C}$ to a particulate fraction was followed in the absence and presence of $100 \mu \mathrm{M} \mathrm{Gpp}[\mathrm{NH}] \mathrm{p}$. Two concentrations ( $4 \mathrm{~nm}$ and $0.35 \mathrm{~nm}$ ) of the radioligand were used. Maximum $\left[{ }^{3} \mathrm{H}\right] \mathrm{BK}$ binding measured with these concentrations by incubation for 90 min on ice is shown in the graph at $t=0$.

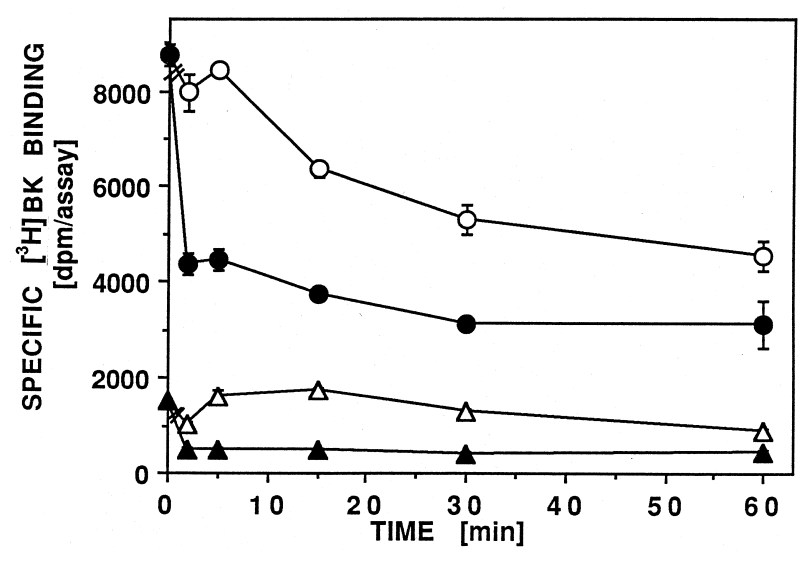

Fig. 1 Time Curve of $\left[{ }^{3} \mathrm{H}\right] \mathrm{BK}$ Binding to Particulate Fractions in the $P$ resence and Absence of $\mathrm{Gpp}[\mathrm{NH}] \mathrm{p}$.

Aliquots of a particulate fraction were incubated with $0.35 \mathrm{~nm}(\triangle$ $\boldsymbol{\Delta})$ and $4 \mathrm{~nm}(\bigcirc, \boldsymbol{O})\left[{ }^{3} \mathrm{H}\right] \mathrm{BK}$ in the absence $(\triangle, \bigcirc)$ orpresence $(\boldsymbol{\Delta}, \boldsymbol{O})$ of $100 \mu \mathrm{M} \mathrm{Gpp}\left[\mathrm{NH}\right.$ ]p at $37^{\circ} \mathrm{C}$ for the indicated times or at $0^{\circ} \mathrm{C}$ for $90 \mathrm{~min}(\mathrm{t}=0)$. Thereafter specific binding was measured as described under Materials and Methods. Values represent the mean of triplicate determinations. Three other experiments gave similar results, with the exemption to the difference between binding at $0^{\circ} \mathrm{C}$ after $90 \mathrm{~min}$ and $37^{\circ} \mathrm{C}$ at $5 \mathrm{~min}$.
In the absence of $\mathrm{Gpp}[\mathrm{NH}] \mathrm{p}$, specific $\left[{ }^{3} \mathrm{H}\right] \mathrm{BK}$ binding activity measured at $37^{\circ} \mathrm{C}$ reached a maximum value for both concentrations after 5 min that declined with time. In the presence of $100 \mu \mathrm{M} \mathrm{Gpp}[\mathrm{NH}] \mathrm{p}$, the binding activity for both $\left[{ }^{3} \mathrm{H}\right] \mathrm{BK}$ concentrations rapidly dropped within $2 \mathrm{~min}$ at $37^{\circ} \mathrm{C}$, reaching a plateau that remained almost unchanged for the subsequent $60 \mathrm{~min}$. This indicates that association and binding reduction induced by the presence of $\mathrm{Gpp}[\mathrm{NH}] \mathrm{p}$ had already reached an equilibrium $2 \mathrm{~min}$ after warming up to $37^{\circ} \mathrm{C}$. Therefore, all subsequent incubations at $37^{\circ} \mathrm{C}$ were performed for $5 \mathrm{~min}$, since at this time point the reduction of specific $\left[{ }^{3} \mathrm{H}\right] \mathrm{BK}$ binding by GTP-analogs was already completed, and problems with the spontaneous reduction of binding activity could also be avoided.

\section{Effect of $\mathrm{Mg}^{2+}$ on Specific B2 Kinin Receptor Binding in the Presence and Absence of $100 \mu \mathrm{M}$ Gpp[NH]p}

In the absence of Gpp[NH]p [ $\left.{ }^{3} \mathrm{H}\right] \mathrm{BK}$ binding activity reached a maximum at about $2 \mathrm{mM} \mathrm{Mg}^{2+}$ (Figure 2 ). Higher concentrations of the divalent cation resulted in a slight reduction of $\left[{ }^{3} \mathrm{H}\right] \mathrm{BK}$ binding. In the presence of $100 \mu \mathrm{M}$ $\mathrm{Gpp}[\mathrm{NH}] \mathrm{p}$ a continuing reduction of $\left.{ }^{3} \mathrm{H}\right] \mathrm{BK}$ binding with increasing $\mathrm{Mg}^{2+}$ concentrations was observed. In the absence of $\mathrm{Mg}^{2+}$ only a minor difference (or none in some experiments) between $\left[{ }^{3} \mathrm{H}\right] \mathrm{BK}$ binding activity in the presence and absence of Gpp[NH]p was obtained. A maximum decline in binding activity induced by $\mathrm{Gpp}$ [NH]p was observed at $\mathrm{Mg}^{2+}$ concentrations higher than $10 \mathrm{~mm}$ (Figure 2, inset). Therefore, all assays were performed in the presence of $25 \mathrm{mM} \mathrm{MgCl}_{2}$ unless otherwise indicated. The divalent cation $\mathrm{Ca}^{2+}$ similarly supported the reduction of binding induced by $\mathrm{Gpp}[\mathrm{NH}] \mathrm{p}$ (not shown).

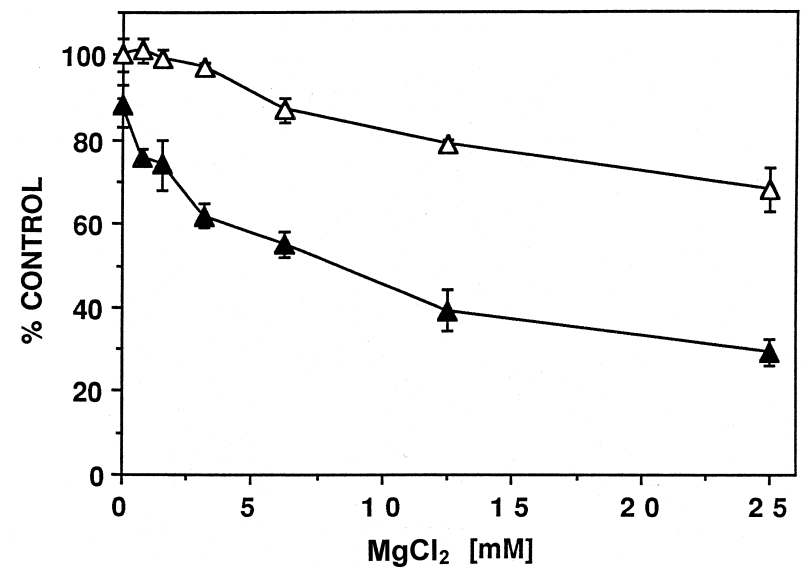

Fig. 2 Influence of $\mathrm{Mg}^{2+}$ on $\left[{ }^{3} \mathrm{H}\right] \mathrm{BK}$ Binding in the Absence and Presence of Gpp[NH]p.

Aliquots of a particulate fractions were incubated with $1.2 \mathrm{~nm}$ $\left[{ }^{3} \mathrm{H}\right] \mathrm{BK}$ and the indicated concentrations of $\mathrm{Mg}^{2+}$ added as chloride salt, for $5 \mathrm{~min}$ at $37^{\circ} \mathrm{C}$ in the absence $(\triangle)$ or presence $(\boldsymbol{\Delta})$ of $100 \mu \mathrm{M}$ Gpp [NH ]p. Subsequently, specific binding was measured as described under Materials and Methods. Values represent the mean of triplicate determinations. A representative experiment out of four is shown. 


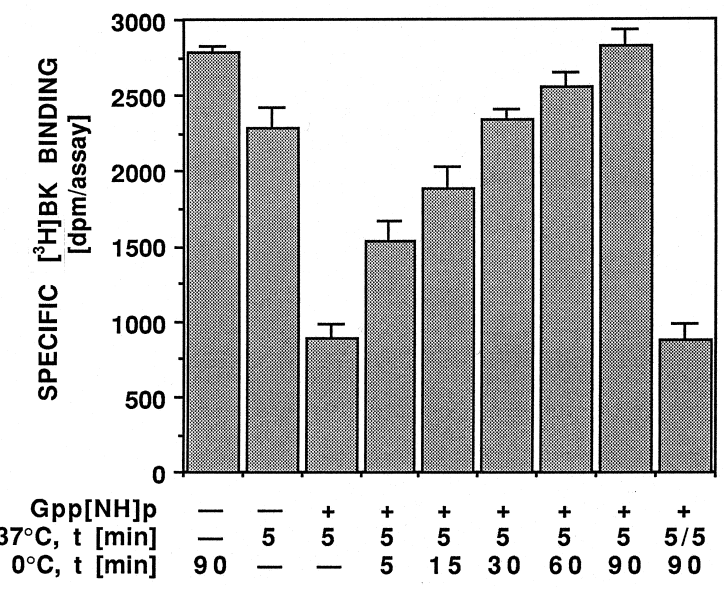

Fig. $\left.3{ }^{3} \mathrm{H}\right] \mathrm{BK}$ Binding Activity at $0^{\circ} \mathrm{C}$ and $37^{\circ} \mathrm{C}$ in the Presence and Absence of Gpp[NH]p.

Aliquots of a particulate fraction were incubated with $2.1 \mathrm{~nm}$ $\left[{ }^{3} \mathrm{H}\right] \mathrm{BK}$ in the absence (-) or presence (+) of $100 \mu \mathrm{M} \mathrm{Gpp}[\mathrm{NH}] \mathrm{p}$ at $0^{\circ} \mathrm{C}$ for 90 min or at $37^{\circ} \mathrm{C}$ for $5 \mathrm{~min}$ followed by an incubation at $0^{\circ} \mathrm{C}$ for the time indicated. In the incubation depicted on the last column reaction vials were again incubated at $37^{\circ} \mathrm{C}$ for $5 \mathrm{~min}$. Thereafter specific binding was measured as described under Materials and Methods. Values represent the mean of triplicate determinations. Another experiment gave similar results.

\section{Effect of Gpp[NH]p on [33 $\mathrm{H}] \mathrm{BK}$ Binding Activity at $0^{\circ} \mathrm{C}$ and $37^{\circ} \mathrm{C}$}

In the experiment shown in Figure $3\left[{ }^{3} \mathrm{H}\right] \mathrm{BK}$ binding activity, measured after an incubation for 5 min at $37^{\circ} \mathrm{C}$, was reduced to about $80 \%$ of the value obtained after an incubation for $90 \mathrm{~min}$ at $0^{\circ} \mathrm{C}$. This difference between binding activity at $0^{\circ} \mathrm{C}$ and $37^{\circ} \mathrm{C}$, however, was very variable from one assay to another. Some preparations showed $a b$ solutely no difference whereas others revealed at $37^{\circ} \mathrm{C}$ only $60 \%$ of the binding activity as compared to that obtained at $0{ }^{\circ} \mathrm{C}$ (not shown). Technical reasons such as the temperature during the preparation, the volume of buffer the cells were suspended in, the time of sonification or centrifugation, the protein amount in the assay, or the influence of reducing agents (addition of dithiothreitol and mercaptoethanol) were excluded as the cause for this interassay variability (not shown). The presence of $100 \mu \mathrm{M}$ $\mathrm{Gpp}[\mathrm{NH}] \mathrm{p}$ at $37^{\circ} \mathrm{C}$ led to a further reduction of $\left[{ }^{3} \mathrm{H}\right] \mathrm{BK}$ binding to about $30 \%$ of the control value obtained at $0^{\circ} \mathrm{C}$. Interestingly, both reducing effects on $\left[{ }^{3} \mathrm{H}\right] \mathrm{BK}$ binding, the one in the absence (not shown) and the one in the presence of $\mathrm{Gpp}[\mathrm{NH}] \mathrm{p}$, were slowly reversed by a subsequent incubation at $0^{\circ} \mathrm{C}$. The full complement of receptor binding activity was restored within $90 \mathrm{~min}$ (Figure 3 ) at $0^{\circ} \mathrm{C}$. A second incubation at $37^{\circ} \mathrm{C}$ again induced a reduction in $\left.{ }^{3} \mathrm{H}\right] \mathrm{BK}$ binding that was similar to the initial effect (Figure 3 , last column).

\section{Reduction of $\left[{ }^{3} \mathrm{H}\right] \mathrm{BK}$ Binding by Various Nucleotides}

Increasing concentrations of various nucleotides were tested for their capability to reduce $\left[{ }^{3} \mathrm{H}\right] \mathrm{BK}$ binding in par- ticulate fractions (Figure 4). Increasing concentrations of all the guanosine nucleotides tested reduced $\left[{ }^{3} \mathrm{H}\right] \mathrm{BK}$ binding in a dose-dependent fashion. The poorly hydrolyzable nucleotides GTP $[\gamma \mathrm{S}]$ and $\mathrm{Gpp}[\mathrm{NH}] \mathrm{p}$ were most efficient with a half-maximal effect at concentrations less than $1 \mu \mathrm{M}$, followed by GTP and GDP with a half-maximal effect at about $3 \mu \mathrm{M}$. The poorly hydrolyzable compound GDP$[\beta S$ ] gave this effect only at concentrations higher than $10 \mu \mathrm{M}$. Maximal reduction was comparable for all nucleotides tested in this experiment, reaching about $30 \%$ of the control value obtained in the absence of nucleotides. No reduction was observed by addition of adenosine nucleotides (ATP, ADP, AM P) or GMP even at high concentrations of $1 \mathrm{~mm}$ (not shown). Since we found no differences in any of our experiments between GTP $[\gamma S$ ]and Gpp [NH ]p in terms of reduction of $\left[{ }^{3} \mathrm{H}\right] \mathrm{BK}$ binding, we used $\mathrm{Gpp}[\mathrm{NH}] \mathrm{p}$ for the subsequent experiments.

\section{Equilibrium Analysis of $\left[{ }^{3} \mathrm{H}\right] \mathrm{BK}$ (Agonist) and $\left[{ }^{3} \mathrm{H}\right]$ NPC 17731 (Antagonist) Binding to Particulate Fractions: Effect of Gpp[NH]p}

Equilibrium binding of the $\mathrm{B} 2 \mathrm{kinin}$ receptoragonist $\left[{ }^{3} \mathrm{H}\right] \mathrm{BK}$ to aliquots of a particulate fraction as a function of $\left[{ }^{3} \mathrm{H}\right] \mathrm{BK}$ concentration is shown in Figure $5 \mathrm{~A}$. At $0^{\circ} \mathrm{C} \mathrm{Gpp[NH]p}$ had no effect on $\left[{ }^{3} \mathrm{H}\right] \mathrm{BK}$ binding (not shown). The binding curves were steep in the absence of $\mathrm{Gpp}[\mathrm{NH}] \mathrm{p}$ at $0^{\circ} \mathrm{C}$ as well as at $37^{\circ} \mathrm{C}$, reaching a plateau at $\left[{ }^{3} \mathrm{H}\right] \mathrm{BK}$ concentrations higher than $15 \mathrm{~nm}$. In the presence of $\mathrm{Gpp}[\mathrm{NH}] \mathrm{p}$ at $37^{\circ} \mathrm{C}$ the binding curve was less steep. Scatchard analysis of these data revealed different receptor affinities, but no difference in maximal binding capacity (Figure $5 \mathrm{~A}$, inset). Only a single category of bind ing sites with a $K_{d}$ of 2.1 nM was found for $\left[{ }^{3} \mathrm{H}\right] \mathrm{BK}$ binding at $0{ }^{\circ} \mathrm{C}$. At $37^{\circ} \mathrm{C}$, in the absence of $\mathrm{Gpp}[\mathrm{NH}] \mathrm{p}$, the Scatchard curve was more complex indicating the presence of more than one binding site.

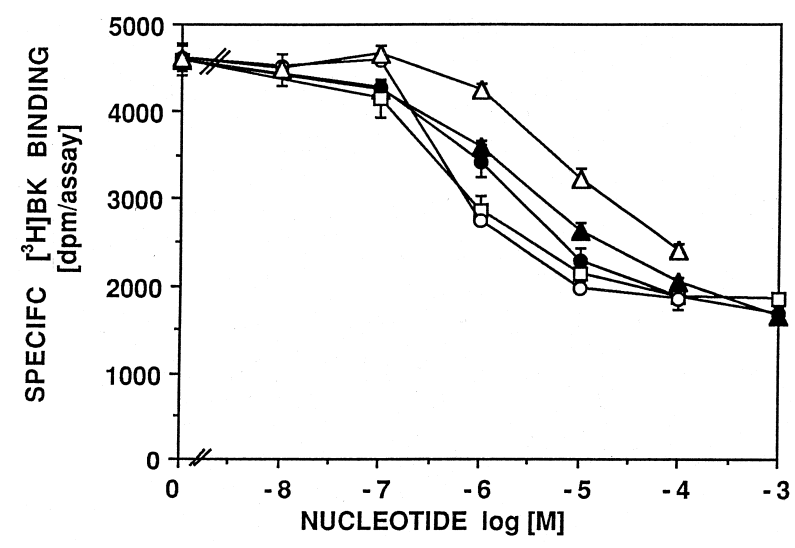

Fig. 4 Inhibition of Specific $\left[^{3} \mathrm{H}\right] \mathrm{BK}$ Binding by Guanosine Nucleotides.

Aliquots of a particulate fraction were incubated with $2 \mathrm{nM}\left[{ }^{3} \mathrm{H}\right] \mathrm{BK}$ and the indicated concentrations of guanosine nucleotides for $5 \mathrm{~min}$ at $37^{\circ} \mathrm{C}$. Thereafter specific binding was measured as described under Materials and M ethods. Values represent the mean of triplicate determinations. (O) GTP $[\gamma \mathrm{S}],(\square) \mathrm{Gpp}[\mathrm{NH}] \mathrm{p},(\mathbf{\bullet}) \mathrm{GTP}$, $(\boldsymbol{\Delta}) \mathrm{GDP},(\triangle) \mathrm{GDP}[\beta \mathrm{S}]$. For each nucleotide at least one other experiment was performed with similar results. 

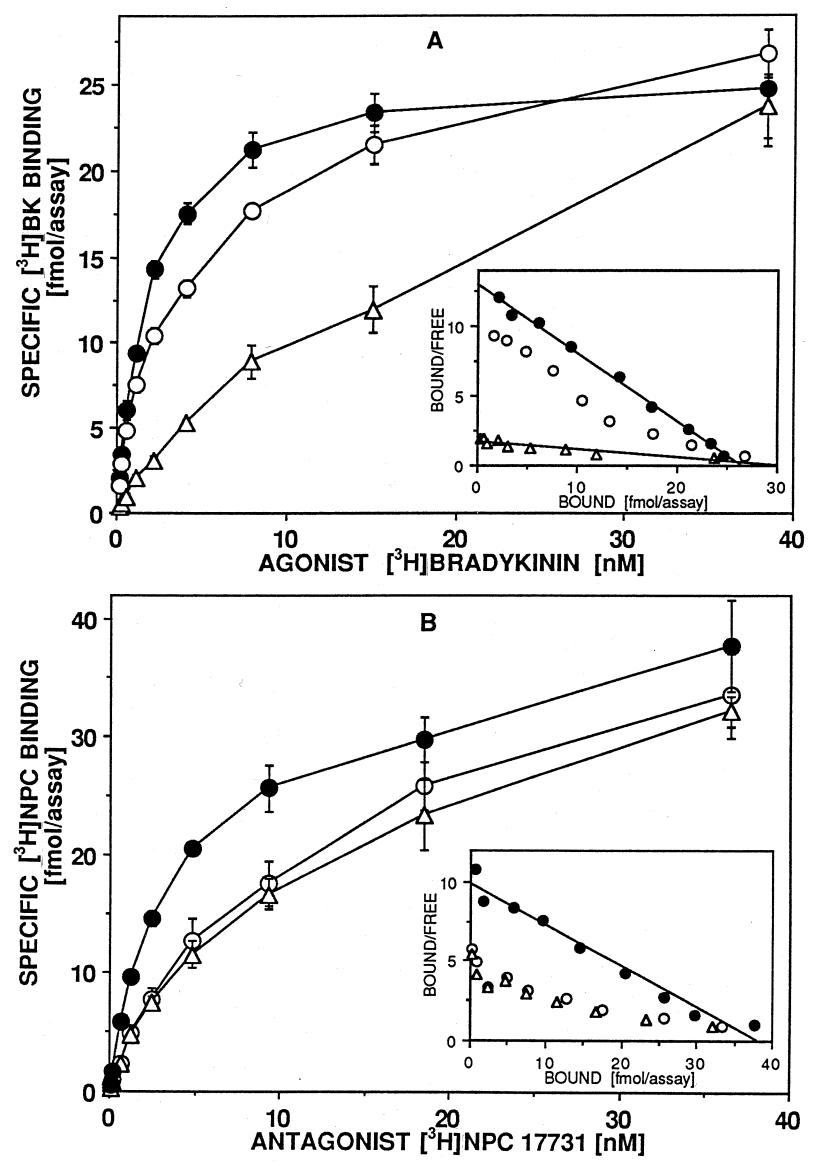

Fig.5 Equilibrium Binding of Agonist $\left[{ }^{3} \mathrm{H}\right] \mathrm{BK}$ and Antagonist $\left[{ }^{3} \mathrm{H}\right] \mathrm{NPC} 17731$ as a Function of Ligand Concentration.

(A) Aliquots of a particulate fraction were incubated with increasing concentrations of $\left[^{3} \mathrm{H}\right] \mathrm{BK}(0.17-38.4 \mathrm{~nm})$ for $5 \mathrm{~min}$ at $37^{\circ} \mathrm{C}(\mathrm{O}$, $\triangle$ ) or for at least $90 \mathrm{~min}$ at $0^{\circ} \mathrm{C}(\bullet)$ in the absence $(O, \bullet)$ or presence $(\triangle)$ of $100 \mu \mathrm{M} \mathrm{Gpp}[\mathrm{NH}] \mathrm{p}$. Thereafter specific binding was measured as described under M aterials and Methods. Each point represents the mean of triplicate determinations. Inset: Scatchard plot of the data. The lines for the data at $0^{\circ} \mathrm{C}$ in the absence of $\mathrm{Gpp}[\mathrm{NH}] \mathrm{p}$ and at $37^{\circ} \mathrm{C}$ in the presence of $\mathrm{Gpp}[\mathrm{NH}] \mathrm{p}$ were computed by linear regression analysis. The equilibrium dissociation constants estimated from the slopes $\left(-1 / \mathrm{K}_{\mathrm{d}}\right)$ were $2.0 \pm 0.5 \mathrm{~nm}$ for binding at $0^{\circ} \mathrm{C}$ and $13.8 \pm 1.1 \mathrm{~nm}$ for binding at $37^{\circ} \mathrm{C}$ in the presence of $100 \mu \mathrm{M} \mathrm{Gpp}[\mathrm{NH}] \mathrm{p}$. The average values including other experiments gave a $K_{d}$ of $2.3 \pm 0.4 \mathrm{~nm}($ mean $\pm S . E, n=4)$ for binding at $0^{\circ} \mathrm{C}$ and $14.6 \pm 4 \mathrm{~nm}($ mean \pm S.E., $n=3)$ for binding at $37^{\circ} \mathrm{C}$ in the presence of $100 \mu \mathrm{M}$ Gpp[NH]p or GTP $[\gamma \mathrm{S}](\mathrm{n}=3)$. (B)A similar experiment is shown with increasing concentrations of antagonist NPC $17731(0.05-36.4 \mathrm{nM})$. Symbols have the same meaning as described in (A). Inset: Scatchard plot of the data in (B). The equilibrium dissociation constant estimated from the slope $\left(-1 / K_{d}\right)$ was $3.8 \pm 0.12 \mathrm{~nm}$. A second experiment gave similar results. Scatchard analysis using the Enzfitter program did not give reasonable results for agonist and antagonist binding at $37^{\circ} \mathrm{C}$ in the absence of Gpp[NH]p, when proposing one binding site or two binding sites with different affinities.

In the presence of $100 \mu \mathrm{M}$ Gpp[N H]p, however, apparently only a single binding site with an affinity of about 15 nM was observed at $37^{\circ} \mathrm{C}$.

Equilibrium binding isotherms of the $\mathrm{B} 2$ kinin receptor antagonist $\left[{ }^{3} \mathrm{H}\right] \mathrm{NPC} 17731$ at $0^{\circ} \mathrm{C}$ and $37^{\circ} \mathrm{C}$ in the pres- ence and absence of $100 \mu \mathrm{M} \mathrm{Gpp[NH]p} \mathrm{are} \mathrm{shown} \mathrm{in}$ Figure $5 \mathrm{~B}$. The binding curve obtained at $0^{\circ} \mathrm{C}$ is distinctly steeper than the curves obtained at $37^{\circ} \mathrm{C}$, which exhibited a similar course regardless of the presence of $100 \mu \mathrm{M}$ $\mathrm{Gpp}[\mathrm{NH}] \mathrm{p}$. The Scatchard analysis of these data revealed only a single bind ing site for antagonist binding at $0^{\circ} \mathrm{C}$ with an apparent $\mathrm{K}_{d}$ of $3.8 \mathrm{nM}$. At $37^{\circ} \mathrm{C}$, however, the Scatchard plot exhibits a bound curve in the absence of Gpp[NH]p, indicating more than one binding site. In addition, this curve was almost identical to the one obtained at $37^{\circ} \mathrm{C}$ in the presence of $\mathrm{Gpp}[\mathrm{NH}] \mathrm{p}$, confirming that antagonist binding to $\mathrm{B} 2$ kinin receptors is not affected by guanosine nucleotides.

\section{Dissociation Kinetics of $\left[^{3} \mathrm{H}\right] \mathrm{BK}$ in the Absence and Presence of $100 \mu \mathrm{M} \mathrm{Gpp}[\mathrm{NH}] \mathrm{p}$ at $37^{\circ} \mathrm{C}$}

In order to test whether the reduction of $\mathrm{B} 2$ kinin receptor affinity by guanosine nucleotides is due to an increase in the dissociation rate, particulate preparations were incubated with $\left[{ }^{3} \mathrm{H}\right] \mathrm{BK}$ for $5 \mathrm{~min}$ at $37^{\circ} \mathrm{C}$ in the presence and absence of Gpp[NH]p. Dissociation was then induced by addition of unlabeled BK (Figure 6). $\left[{ }^{3} \mathrm{H}\right] \mathrm{BK}$ dissociated rapidly in the presence and absence of $\mathrm{Gpp}[\mathrm{NH}]$, whereas control binding remained almost unchanged. The semilogarithmic plot of the data, normalized to the initial value as $100 \%$ (Figure 6 , inset), however, clearly shows that the dissociation is faster in the presence than in the absence of Gpp[NH]p.

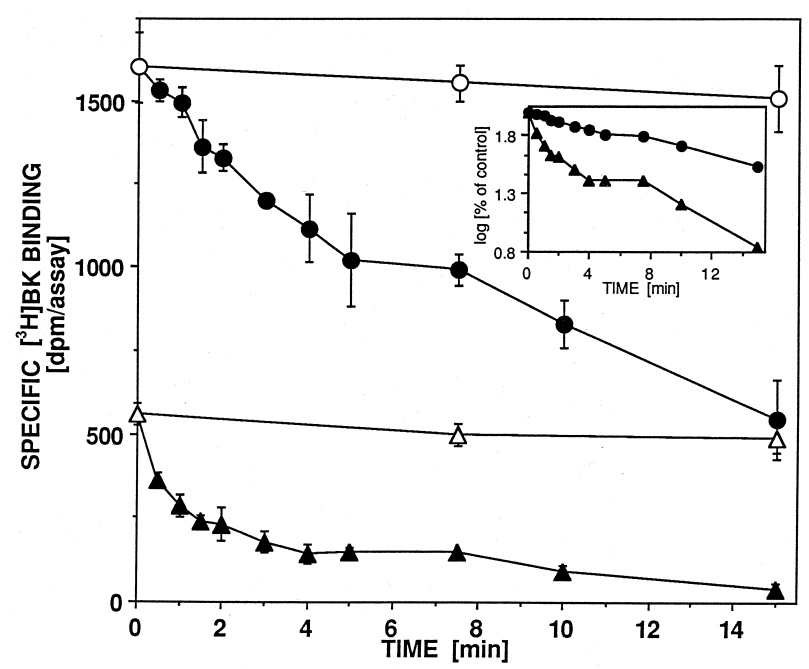

Fig. 6 Dissociations Kinetics of $\left[{ }^{3} \mathrm{H}\right] \mathrm{BK}$ in the Absence and Presence of Gpp[NH]p.

Aliquots of a particulate fraction were incubated with $2.1 \mathrm{~nm}$ $\left[{ }^{3} \mathrm{H}\right] \mathrm{BK}$ in the absence $(O, \boldsymbol{\bullet})$ or presence $(\triangle, \boldsymbol{\Delta})$ of $100 \mu \mathrm{M}$ $\mathrm{Gpp}[\mathrm{NH}] \mathrm{p}$ for $5 \mathrm{~min}$ at $37^{\circ} \mathrm{C}$. Dissociation $(\boldsymbol{\bullet}, \mathbf{\Delta})$ at $37^{\circ} \mathrm{C}$ was initiated by addition of unlabeled BK (5 $\mu \mathrm{m}$ final concentration). Specific binding was measured at the indicated times as described under Materials and Methods. Control values without addition of $B K$ are also shown $(O, \triangle)$. Values represent the mean of triplicate determinations. Inset: Semi-logarithmic plot of the dissociation data, normalized to the control values at $\mathrm{t}=0$, using the same symbols. 


\section{Discussion}

Depending on the tissue source or cell line under study BK is reported to stimulate, or to inhibit, a variety of signal transduction pathways. The role of $G$ proteins, however, in the variety of $B K$ signal cascades is not fully elucidated. Human foreskin fibroblasts expressing high numbers of B2 kinin receptor have already been shown to be an excellent tool to study the regulation and the properties of the human B 2 kinin receptor, as well as its signal transduction pathways (Roscher et al., 1983, 1984; Dengler et al., 1990; Faussner et al., 1991). Therefore, we decided to use this cell system to investigate the regulatory role of guanosine nucleotides in the binding of agonist and antagonist to B2 kinin receptors in particulate fractions of human foreskin fibroblasts.

In the presence of GTP, GDP, and their poorly hydrolyzable analogs there was a reduction in agonist $\left(\left[{ }^{3} \mathrm{H}\right] \mathrm{BK}\right)$, but not antagonist ( $\left.\left[{ }^{3} \mathrm{H}\right] \mathrm{NPC} 17731\right)$ binding affinity in particulate fractions of human forskin fibroblasts at $37^{\circ} \mathrm{C}$.

This effect was dependent on the presence of divalent cations, particularly $\mathrm{Mg}^{2+}$. In the absence of $\mathrm{Mg}^{2+}$ there was only a minimal reduction of binding activity upon addition of guanosine nucleotides. This dependence on divalent cations may explain the observed lack of reduction of $\left[{ }^{3} \mathrm{H}\right] \mathrm{BK}$ binding to guinea pig lung membranes by GTP analogs (Trifilieff et al., 1994), since $\mathrm{Mg}^{2+}$ was not included in the incubation buffer in these studies. As suggested by Keravis et al. (1991), the regulation of receptors by $G$ proteins may vary depending on differences in species or tissues. They observed an inhibition of BK binding to B 2 kinin receptors in membranes of bovine endothelial cells by GTP, GDP, GTP $[\gamma S$ ], and GDP[ $\beta S$ ]. This inhibitory effect, however, did not depend on the presence of $\mathrm{Mg}^{2+}$. Indeed, in contrast to our results in fibroblasts, the described effect was almost completely blocked by addition of $5 \mathrm{~mm}$ $\mathrm{MgCl}_{2}$ or $5 \mathrm{mM} \mathrm{CaCl}_{2}$. In particulate fractions of fibroblasts we found only a single bind ing site with $\mathrm{K}_{d}$ of $2.3 \mathrm{~nm}$ in the presence of $25 \mathrm{mM} \mathrm{Mg}^{2+}$ at $0^{\circ} \mathrm{C}$. As already described for other B2 kinin receptor assays, $\mathrm{Mg}^{2+}(25 \mathrm{~mm})$ reduced agonist affinity, since we obtained a higher $\mathrm{K}_{d}$ of $0.7 \mathrm{nM}$ at $0^{\circ} \mathrm{C}$ in the absence of $\mathrm{Mg}^{2+}$ (not shown).

A spontaneous reduction of binding activity was observed for agonist and antagonist upon incubation at $37^{\circ} \mathrm{C}$. Scatchard analysis of equilibrium binding curves revealed that the reduction in binding activity is the consequence of a change in the affinity of at least a part of the receptors and is not due to a decrease in receptor number. Thus, one can assume that under certain conditions B2 kinin receptors in particulate fractions can change their affinity even in the absence of exogenous guanosine nucleotides. Addition of GTP derivatives led to a further reduction of agonist binding but not antagonist binding. Scatchard analysis of equilibrium binding of agonist $\left(\left[{ }^{3} \mathrm{H}\right] \mathrm{BK}\right)$ and antagonist $\left.\left({ }^{3} \mathrm{H}\right] \mathrm{NPC} 17731\right)$ binding revealed that at $0^{\circ} \mathrm{C}$ there is only one single category of binding sites with a dissociation constant $\left(K_{d}\right)$ of $2.3 \pm 0.4 \mathrm{nM}$ (mean \pm S. E., $n=4)$ for $\left[{ }^{3} \mathrm{H}\right] \mathrm{BK}$ and $\mathrm{a} \mathrm{K}_{\mathrm{d}}$ of $3.8 / 5.2 \mathrm{~nm}(\mathrm{n}=2)$ for $\left[{ }^{3} \mathrm{H}\right] \mathrm{NPC} 17731$. In membranes of bovine aortic endothelial cells the existence of a high-affinity B2 binding site has been reported for $\mathrm{BK}$ at $0{ }^{\circ} \mathrm{C}$, that even at this temperature in the presence of $100 \mu \mathrm{M} \mathrm{Gpp[NH]p} \mathrm{is}$ changed to a low-affinity site by incubation for $90 \mathrm{~min}$ (Liao and Homcy, 1993). Our results with foreskin fibroblasts are completely different, since incubation at $0^{\circ} \mathrm{C}$ actually reversed a prior change in affinity induced at $37^{\circ} \mathrm{C}$ (Figure 3). This different influence of the temperature on B2 kinin receptor affinity reduction by guanosine nucleotides may reflect a species-specific difference or might be due to coupling of the $B 2$ kinin receptor to different $G$ proteins in different cell types.

The binding reduction observed for agonist and antagonist binding after an increase of temperature from $0{ }^{\circ} \mathrm{C}$ to $37^{\circ} \mathrm{C}$ seems to be due to the change in the affinity of a part of the receptors, as can be seen from the Scatchard plots. In the presence of GTP $[\gamma S]$ or Gpp[NH ]p at $37^{\circ} \mathrm{C}$ only a low-affinity site for the agonist with a $K_{d}$ of $14.6 \pm$ $4 \mathrm{~nm}$ (mean \pm S. E., $\mathrm{n}=3$ ) was seen. Dissociation kinetics demonstrate that this reduction of receptor affinity by guanosine nucleotides is due to an increase of the dissociation rate for $\left[{ }^{3} \mathrm{H}\right] \mathrm{BK}$ (Figure 6 ), as also suggested by other reports (Leeb-Lundberg and Mathis, 1990). These results clearly indicate that in human foreskin fibroblasts $G$ proteins influence the affinity but not the number of $B 2$ kinin receptors in particulate fractions. This is in contrast to previous results reported by others (Etscheid and Villereal, 1989) who observed a $45 \%$ reduction in B2 kinin receptor number in the presence of $100 \mu \mathrm{M}$ GTP $[\gamma \mathrm{S}]$ in human foreskin fibroblasts.

GTP, GDP and their poorly hydrolyzable analogs GTP $[\gamma S$ ], Gpp [NH]p and GDP [ $\beta S$ ] were all capable of reducing $\left[{ }^{3} \mathrm{H}\right] \mathrm{BK}$ binding in particulate fractions; the poorly hydrolyzable analogs GTP $[\gamma \mathrm{S}]$ and Gpp[NH]p showed highest potencies with $I C_{50}$ values around $1 \mu \mathrm{M}$, followed by GTP and GDP (IC 50 about $3 \mu \mathrm{M})$ and GDP [ $\beta S$ ] $\left(I C_{50}\right.$ about $10 \mu \mathrm{M}$ ). GMP and adenosine nucleotides (ATP, ADP, AMP) showed no effect (not shown). Similar potencies of these nucleotides have been reported for the reduction of B2 kinin receptors in bovine endothelial cells (Keravis et al., 1991), for the $\beta$-adrenergic receptor (Lefkowitz et al., 1976), and for the $\alpha$-adrenergic receptor (Rouot et al., 1980). The observation that not only GTP but also GDP exerts a strong effect on agonist binding to B2 kinin receptors has important implications when considering any hypothesis for the interaction of the B2 kinin receptor with $\mathrm{G}$ proteins.

Results derived from dissociation studies in the presence and absence of Gpp[NH]p (Leeb-Lundberg and Mathis, 1990) led to the suggestion that the B2 kinin receptor may exist in at least two different states that display different affinities depending on coupling to a $G$ protein. In bovine myometrium, the B2 kinin receptor has been suggested to exhibit a high-affinity binding site when coupled to a $\mathrm{G}$ protein, and a low-affinity binding site when uncoupled. Building on this assumption, the similar effects of GTP and GDP in ourcurrentstudy may be explained by the 
existence of an intermediate ternary complex of agonist, receptor and $G$ protein, that is only stable in the absence of GTP and GDP as suggested by others (De Lean et al., 1980; Haga and Haga, 1987; Keravis et al., 1991). Since GTP and GDP are almost completely lost during the preparation of the particulate fraction, the receptor should remain coupled to the $G$ protein while exhibiting high affinity for the agonist. Under these circumstances our results would imply that GTP or GDP are able to bind to the G protein in this ternary complex only in the presence of an agonist and thereby promote dissociation of the ternary complex. One would also expect neither binding of GTP/GDP to the ternary complex at $0^{\circ} \mathrm{C}$ nor dissociation of this complex, since receptor affinity was not influenced at this temperature.

At $0{ }^{\circ} \mathrm{C}$ the agonist binds to $\mathrm{B} 2$ kinin receptors only with high affinity. The same appears to be the case for antagonist binding. This, however, can be only deduced indirectly by the fact that an increase of temperature from $0^{\circ} \mathrm{C}$ to $37^{\circ} \mathrm{C}$ leads to lower affinities for antagonist binding (Figure $5 \mathrm{~B}$ ) without apparent loss in receptor number. Several other experiments using antagonist concentrations close to $3 \mathrm{nM}$ at $37^{\circ} \mathrm{C}$ gave variable binding reductions, ranging between $0 \%$ and $40 \%$ as compared to values obtained at $0{ }^{\circ} \mathrm{C}$. Experiments were performed with prior incubation of particulate fractions with $0.5 \mathrm{~nm}$ unlabeled $\mathrm{BK}$ in the absence (mainly high-affinity state) and presence of $100 \mu \mathrm{M}$ $\mathrm{Gpp}[\mathrm{NH}] \mathrm{p}$ for $5 \mathrm{~min}$ (to induce the low-affinity state). Subsequent assays for 5 min at $37^{\circ} \mathrm{C}$ with $8 \mathrm{~nm}\left[{ }^{3} \mathrm{H}\right] \mathrm{NPC} 17731$ resulted in almost identical antagonist binding activities in both pretreatment groups (not shown). This may suggest that antagonist binding is capable of reversing the affinity reduction, induced by an agonist in the presence of guanosine nucleotides, or that a B2 kinin receptor after dissociation of the agonist immediately returns to its highaffinity conformation. A third explanation taking into account the different consequences of mutations on agonist and antagonist binding (Nardone and Hogan, 1994) may be that the antagonist is not able to differentiate between the high- and the low-affinity states.

Taken together these results are best explained by a model (Figure 7) in which B2 kinin receptors (R) are precoupled to $G$ proteins $(G)$ with an empty guanosine nucleotide binding site in the absence of agonist (B) as well as in the presence of antagonist $(\mathrm{N})$. The preceding release of GDP from this receptor-G protein-complex should be fast, not depending on the presence of an agonist. This proposal is also supported by the results of Mathis and Leeb-Lundberg (1991) showing a sensitivity to Gpp[NH]p of soluble $B 2$ kinin receptors of bovine myometrium even when the receptors have been solubilized in the absence of agonist. We have previously shown that gel filtration of B2 kinin receptors solubilized from human foreskin fibroblasts (Faussner et al., 1991) gave an apparent molecular mass for the B2 kinin receptor that was much higher (approximately $250 \mathrm{kDa}$ ) than would be expected by the calculated molecular mass of $41 \mathrm{kDa}$ deduced from cDNA analysis (Hess et al., 1992) or by the molecular mass of

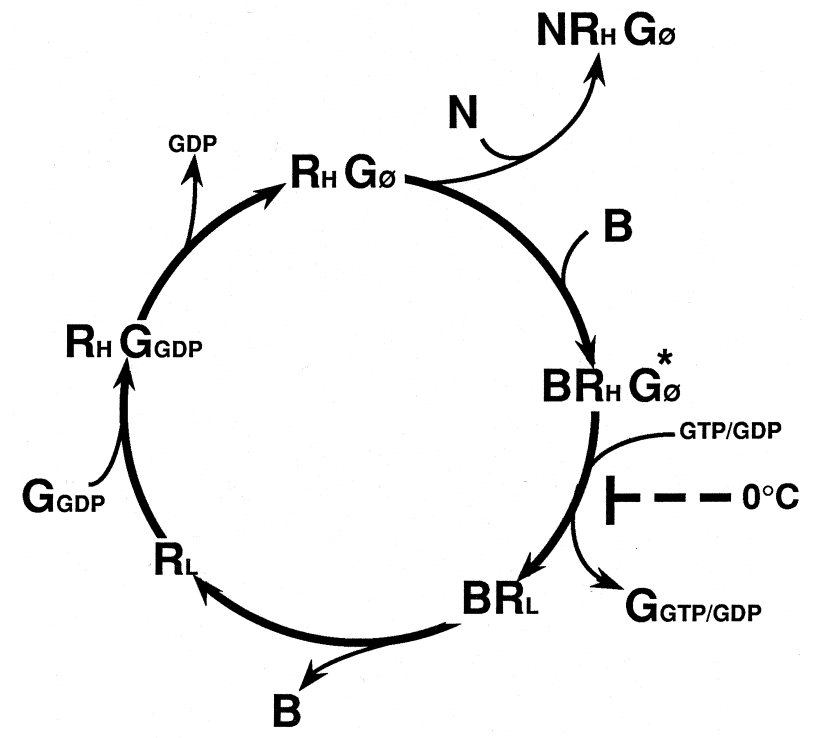

Fig. 7 Proposed Model for the Interaction of the B2 Kinin Receptor with a $\mathrm{G}$ Protein.

$B$, agonist; $N$, antagonist; $R_{H}$ high-affinity receptor; $R_{L}$, low-affinity receptor; $G_{\emptyset}, G$ protein without and inaccessible for guanosine nucleotide; $G_{\varnothing} *, G$ protein without bound, but accessible for guanosine nucleotide. The model is explained in the Discussion section.

about $68 \mathrm{kDa}$ that has been found by immunoprecipitation and affinity cross-linking (Abd Alla et al., 1993). This fact may well be due to co-solubilization of coupled G protein(s). According to the model in Figure 7, one could speculate that the major task of an agonist is to open the receptor-coupled $G$ protein for binding of either GTP or GDP. Only binding of GTP would relay a signal; however, due to the prevalence of this guanosine nucleotide in the cell this is almost always the case. Furthermore, opening of the $\mathrm{G}$ proteins for guanosine nucleotides by agonists should happen only at $37^{\circ} \mathrm{C}$, but not at $0^{\circ} \mathrm{C}$, and should be blocked by occupation of the receptor with antagonist. Therefore, one can assume that in the absence of an agonist and in the presence of an antagonist, or at $0^{\circ} \mathrm{C}, \mathrm{a}$ complex is formed consisting of $G$ proteins having no guanosine nucleotide bound and of B2 kinin receptors exhibiting a high-affinity binding for agonist as well as for antagonists. This would explain the co-solubilization of $B 2$ kinin receptors and $G$ proteins. A recent publication describing that antagonists like NPC 17731 and Hoe140 may act as inverse agonists in rat myometrial cells supposed that the antagonists bind to and stabilize a $\mathrm{G}$ protein uncoupled state of the B2 kinin receptor (Leeb-Lundberg et al., 1994). It should therefore be a low-affinity binding state, always provided that the antagonist is able to discriminate between high- and low-affinity states. In our opinion, however, these data do not demonstrate experimentally that the antagonists preferentially bind to the $G$ protein uncoupled state. The reported fact that antagonists may act as inverse agonists could also be explained by the assumption of a spontaneous opening of the $G$ protein for GTP in the coupled, unoccupied receptor state, 
leading to the dissociation of an activated $\mathrm{G}$ protein. If occupation of the receptor with an antagonist reduces this spontaneous activation of the coupled $\mathrm{G}$ protein, this antagonist would behave like an inverse agonist.

Transfer of the C-terminus of the internalizing B 2 kinin receptor to the normally not internalizing $B 1$ kinin receptor resulted in almost completed transfer of the internalization pattern, i. e. the receptor chimera responded to stimulation with a B1 kinin receptor agonist with fast receptor internalization (Faussner et al., 1998), despite the fact that the two receptors have only an overall homology of $36 \%$ and even less when comparing only the intracellular domains. This result could be easily explained assuming that the internalization process does not require a specific interaction of the remaining part of the receptor with its C terminus but requires only access of the internalization machinery to the $\mathrm{C}$-terminus. In the proposed model of a precoupled receptor this access, however, would sterically be blocked by the $\mathrm{G}$ protein, thus allowing receptor internalization only after agonist stimulation and following activation/release of the blocking $\mathrm{G}$ protein.

Our model shown in Figure 7 contrasts somewhat to models developed for other $\mathrm{G}$ protein-coupled receptors (e.g. the muscarinic receptor, where coupling to $G$ proteins is supposed to be a consequence of agonist binding; De Lean et al., 1980; Haga and Haga, 1987; Freissmuth et al., 1989). Nonetheless, since the $G$ protein-coupled receptors apparently not even share the same seven-transmembrane domain structure as indicated by the fact that the B2 kinin receptor in particular apparently does not have three but only two internal loops (Quitterer et al., 1999) and that they are composed of internal loops and $\mathrm{C}$-termini of very different amino acid composition and length, their regulation by $\mathrm{G}$ proteins may also well be very different.

\section{Materials and Methods}

\section{Materials}

[2,3-prolyl-3,4- ${ }^{3} \mathrm{H}$ ]bradykinin (108 Ci/mmol) and [prolyl-3,4- ${ }^{3} \mathrm{H}$ NPC17731 (48.5 Ci/mmol) were obtained from Du Pont-New England Nuclear (Boston, MA, USA). All nucleotides were from Boehringer Mannheim (Mannheim, Germany). Unlabeled BK and all other reagents were from Sigma (Deisenhofen, Germany). Hoel40 was a gift from Dr. B. Schoelkens (Hoechst, Frankfurt, Germany).

\section{Cell Culture}

Two lines of foreskin fibroblasts (\# 7241 and \#1634) were purchased from ATCC (Rockville, MD, USA). Cells were used between the 5th and 19th passage. Stock cultures were grown in Eagle's basal medium supplemented with Earle's salts, 10\% fetal calf serum, and $2 \mathrm{~mm}$ glutamine, as described previously (Faussner et al., 1991). For all experiments confluent stock cultures were trypsinized and split 1:5-1:8 on tissue culture dishes (100 or $145 \mathrm{~mm}$ diameter). Medium was changed after 4-7 days and subcultures were used upon reaching confluence usually 7 to 14 days after seeding.

\section{Preparation of Particulate Fibroblast Fractions}

Confluentcell monolayers were washed with a hypotonic solution $\left(\mathrm{H}_{2} \mathrm{O}\right)$ at room temperature and scraped off in ice-cold $20 \mathrm{~mm}$ PIPES-buffer, adjusted to $\mathrm{pH} 6.8$ with $\mathrm{KOH}$, containing $2 \mathrm{~mm} \mathrm{bac}$ itracin and $25 \mathrm{mM} \mathrm{MgCl}$ (PBM-buffer), and disrupted by sonification. Thereafter, the homogenate was centrifuged at $4{ }^{\circ} \mathrm{C}$ at $30000 \mathrm{~g}$ for $15 \mathrm{~min}$. For radioligand binding studies the pellets were resuspended by sonification in ice-cold PBM-buffer (unless otherwise indicated).

\section{Binding Assay with $\left[{ }^{3} \mathrm{H}\right] \mathrm{BK}$ or $\left[{ }^{3} \mathrm{H}\right] \mathrm{NPC} 17731$}

Binding of $\left[{ }^{3} \mathrm{H}\right] \mathrm{BK}$ and $\left[{ }^{3} \mathrm{H}\right] \mathrm{NPC} 17731$ to homogenates and particulate fractions of fibroblasts was performed as described previously (Faussner et al., 1991) with slight modifications. 100 or $200 \mu \mathrm{l}$ of an ice-cold suspension of a particulate fraction, corresponding to $15-45 \mu \mathrm{g}$ protein, were added to reaction vials placed on ice. Nucleotides and other agents were added as 100 fold concentrated solutions, while $\mathrm{MgCl}_{2} \times 6 \mathrm{H}_{2} \mathrm{O}$ and $\mathrm{CaCl}_{2} \times$ $2 \mathrm{H}_{2} \mathrm{O}$ were added as 50 -fold concentrated solutions, as indicated in the Figure legends. A volume equal to that of the particulate fraction of PBM-buffer was added containing appropriate concentrations of $\left[{ }^{3} \mathrm{H}\right] \mathrm{BK}$ or $\left[{ }^{3} \mathrm{H}\right] \mathrm{NPC} 17731$ without (for determination of total binding), or with $5 \mu \mathrm{M}$ unlabeled BK or $5 \mu \mathrm{M}$ Hoel40 (in antagonist studies) for determination of nonspecific binding. For binding studies at $0^{\circ} \mathrm{C}$, the incubation mixture was shaken and further incubated for at least $90 \mathrm{~min}$ on ice. Binding studies at $37^{\circ} \mathrm{C}$ were performed by transferring the ice-cold incubation mixture to a water bath. Incubations were then continued for $5 \mathrm{~min}$ unless otherwise indicated. Separation of protein-bound ligand from free ligand was obtained by rapid filtration through glass fiber filters (Whatman GF/C), presoaked in ice-cold $0.3 \%$ polyethylenimine. The filters were rapidly washed with ice-cold $14 \%$ isopropyl alcohol $(3 \times 4 \mathrm{ml})$, using a filtration device (Hoeffer Instruments, San Francisco, CA, USA) and the filter-bound radioactivity was determined after addition of $3 \mathrm{ml} \mathrm{scintillation} \mathrm{liquid.}$ Specific binding was calculated as the difference between total and nonspecific binding. In typical experiments using $\left[{ }^{3} \mathrm{H}\right] \mathrm{BK}$ at a concentration of approximately $2 \mathrm{~nm}$, nonspecific binding was less than $20 \%$ of total binding; that of $\left[{ }^{3} \mathrm{H}\right] \mathrm{NPC} 17731$ at a concentration of $4 \mathrm{~nm}$ was less than $30 \%$. Data calculation and bestcurve fits were made using the Enzfitter program from Biosoft (Ferguson, MO, USA).

\section{Protein Determination}

Concentrations of protein were measured according to the method of Bradford using bovine serum albumin as a standard (Bradford, 1976).

\section{Acknowledgement}

This work was supported by the Sonderforschungsbereich 207 of the University of Munich, project F4.

\section{References}

Abd Alla, S.A., Buschko, J ., Quitterer, U., Maidhof, A., Haasemann, M., Breipohl, G., Knolle, J ., and Müller-Esterl, W. (1993). Structural features of the human bradykinin B2 receptor probed by agonists, antagonists, and anti-idiotypic antibodies. J. Biol.Chem. 268, 17277-17285. 
Bathon, J.M., and Proud, D. (1991). Bradykinin antagonists. Annu. Rev. Pharmacol. Toxicol. 31, 129-162.

B hoola, K.D., Figueroa, C.D., and Worthy, K. (1992). Bioregulation of kinins: kallikreins, kininogens, and kininases. Pharmacol. Rev. 44, 1-80.

Bradford, M.M. (1976). A rapid and sensitive method for the quantitation of microgram quantities of protein utilizing the principle of protein-dye binding. Anal. Biochem. 72, 248- 254.

Burch, R.M., and Axelrod, J . (1987). Dissociation of bradykinininduced prostaglandin formation from phosphatidylinositol turnover in Swiss $3 \mathrm{~T} 3$ fibroblasts: evidence for $\mathrm{G}$ protein regulation of phospholipase A2. Proc. Natl. Acad. Sci. USA 84, $6374-6378$.

De Lean, A., Stadel, J .M., and Lefkowitz, R.J . (1980). A ternary complex model explains the agonist-specific binding properties of the adenylate cyclase-coupled beta-adrenergic receptor. J. Biol. Chem. 255, 7108-7117.

Dengler, R., Faussner, A., Müller-Esterl, W., and Roscher, A.A. (1990). [Hyp3]-bradykinin and [Hyp3]-Lys-bradykinin interact with B2-bradykinin receptors and stimulate inositol phosphate production in cultured human fibroblasts. FEBS Lett. 262, $111-114$.

Etscheid, B.G., and Villereal, M.L. (1989). Coupling of bradykinin receptors to phospholipase $C$ in cultured fibroblasts is mediated by a G-protein. J . Cell. Physiol. 140, 264 - 271.

Farmer, S.G., and Burch, R.M. (1992). Biochemical and molecular pharmacology of kinin receptors. Annu. Rev. Pharmacol. Toxicol. 32, 511- 536 .

Faussner, A., Heinz-Erian, P., Klier, C., and Roscher, A.A. (1991). Solubilization and characterization of $\mathrm{B} 2$ bradykinin receptors from cultured human fibroblasts. J. Biol. Chem. 266, $9442-$ 9446.

Faussner, A., Proud, D., Towns, M., and Bathon, J.M. (1998). Influence of the cytosolic carboxyl termini of human B1 and B2 kinin receptors on receptor sequestration, ligand internalization, and signal transduction. J. Biol. Chem. 273, 2617- 2623.

Freissmuth, M., Casey, P.J ., and Gilman, A.G. (1989). G proteins control diverse pathways of transmembrane signaling. FASEB J. 3, 2125-2131.

Gutowski, S., Smrcka, A., Nowak, L., Wu, D.G., Simon, M., and Sternweis, P.C. (1991). Antibodies to the alpha q subfamily of guanine nucleotide-binding regulatory protein alpha subunits attenuate activation of phosphatidylinositol 4,5-bisphosphate hydrolysis by hormones. J . Biol. Chem. 266, 20519- 20524.

Haga, T., and Haga, K. (1987). Interaction of the muscarinic acetylcholine receptor and GTP-binding proteins. Biomed. Res. 8, 149-156.

Hess, J .F., Borkowski, J .A., Young, G.S., Strader, C.D., and Ransom, R.W. (1992). Cloning and pharmacological characterization of a human bradykinin (BK-2) receptor. Biochem. Biophys. Res. Commun. 184, $260-268$

Keravis, T.M., Nehlig, H., Delacroix, M.F., Regoli, D., Hiley, C.R., and Stoclet, J.C. (1991). High-affinity bradykinin B2 binding sites sensitive to guanine nucleotides in bovine aortic endothelial cells. Eur. J. Pharmacol. 207, 149-155.

Leeb-Lundberg, L.M., and Mathis, S.A. (1990). Guanine nucleotide regulation of $\mathrm{B} 2$ kinin receptors. Time-dependent formation of a guanine nucleotide-sensitive receptor state from which $\left[{ }^{3} \mathrm{H}\right]$ bradykinin dissociates slowly. J . Biol. Chem. 265 , 9621- 9627.

Leeb-Lundberg, L.M., Mathis, S.A., and Herzig, M.C. (1994). Antagonists of bradykinin that stabilize a G-protein-uncoupled state of the $B 2$ receptor act as inverse agonists in rat myometrial cells. J . Biol. Chem. 269, 25970- 25973.
Lefkowitz, R.J ., Mullikin, D., and Caron, M.G. (1976). Regulation of beta-adrenergic receptors by guanyl-5'-yl imidodiphosphate and other purine nucleotides. J. Biol. Chem. 251, 4686 4692.

Liao, J .K., and Homcy, C.J . (1993). The G proteins of the G alpha i and $\mathrm{G}$ alpha q family couple the bradykinin receptor to the release of end othelium-derived relaxing factor. J . Clin. Invest. 92, $2168-2172$

Liebmann, C., and Reissmann, S. (1990). Bradykinin inhibits rat myometrial adenylate cyclase activity via a high-affinity receptor. Biomed. Biochim. Acta. 49, 1231- 1234.

Liebmann, C., Schnittler, M., Nawrath, S., and J akobs, K.H. (1991). High-affinity bradykinin receptor-catalyzed G protein activation in rat myometrium. Eur. J. Pharmacol. 207, 67-71.

Mathis, S.A., and Leeb-Lundberg, L.M. (1991). Bradykinin recognizes different molecular forms of the $\mathrm{B} 2$ kinin receptor in the presence and absence of guanine nucleotides. Biochem. J . 276, 141-147.

McEachern, A.E., Shelton, E.R., Bhakta, S., Obernolte, R., Bach, C., Zuppan, P., Fujisaki, J., Aldrich, R.W., and J arnagin, K. (1991). Expression cloning of a rat B2 bradykinin receptor. Proc. Natl. Acad. Sci. USA 88, 7724 - 7728.

Menke, J .G., Borkowski, J .A., Bierilo, K.K., MacNeil, T., Derrick, A.W., Schneck, K.A., Ransom, R.W., Strader, C.D., Linemeyer, D.L., and Hess, J.F. (1994). Expression cloning of a human B1 bradykinin receptor. J . Biol. Chem. 269, 21583-21586.

Nardone, J ., and Hogan, P.G. (1994). Delineation of a region in the $B 2$ bradykinin receptor that is essential for high-affinity agonist binding. Proc. Natl. Acad. Sci. USA 91, 4417- 4421.

Proud, D., and Kaplan, A.P. (1988). Kinin formation: mechanisms and role in inflammatory disorders. Annu. Rev. Immunol. 6, 4983.

Quitterer, U., Zaki, E., and AbdAlla, S. (1999). Investigation of the extracellular accessibility of the connecting loop between membrane domains I and II of the bradykinin B2 receptor. J . Biol. Chem. 274, 14773-14778.

Regoli, D., and Barabe, J . (1988). Kinin receptors. Meth. Enzymol. 163, 210- 230.

Roscher, A.A., Manganiello, V.C., J elsema, C.L., Moss, J ., and Vaughan, M. (1983). Regulation by bradykinin of its receptor and of receptor-mediated prostacyclin formation in cultured human fibroblasts. Trans. Assoc. Am. Physicians. 96, 175181.

Roscher, A.A., Manganiello, V.C., J elsema, C.L., and Moss, J . (1984). Autoregulation of bradykinin receptors and bradykinininduced prostacyclin formation in human fibroblasts. J. Clin. Invest. 74, $552-558$.

Rouot, B.M., U'Prichard, D.C., and Snyder, S.H. (1980). Multiple alpha 2-noradrenergic receptor sites in rat brain: selective regulation of high-affinity $\left[{ }^{3} \mathrm{H}\right]$ clonidine binding by guanine nucleotides and divalent cations. J. Neurochem. 34, 374- 384.

Tippmer, S., Quitterer, U., Kolm, V., Faussner, A., Roscher, A., Mosthaf, L., Müller-Esterl, W., and Haring, H. (1994). B radykinin induces translocation of the protein kinase $\mathrm{C}$ isoforms alpha, epsilon, and zeta. Eur. J . Biochem. 225, 297- 304

Trifilieff, A., Lach, E., Mousli, M., Haddad, E.B., Landry, Y., and Gies, J .P. (1994). Co-solubilization of bradykinin B2 receptors and angiotensin-converting enzyme from guinea pig lung membranes. Biochim. Biophys. Acta 1191, 109-116.

Webb, M., McIntyre, P., and Phillips, E. (1994). B1 and B2 bradykinin receptors encoded by distinct mRNAs.J. Neurochem. 62, 1247-1253.

Received February 15, 2000; accepted February 17, 2000 